\title{
PENGARUH STRATEGI PEMBELAJARAN DAN GAYA BELAJAR TERHADAP HASIL BELAJAR GAMBAR TEKNIK MESIN SISWA SMK DI MEDAN
}

\author{
R. Mursid \\ Fakultas Teknik, Pascasarjana Universitas Negeri Medan \\ mursid.tp@gmail.com
}

\begin{abstract}
Abstrak: Tujuan dari penelitian ini adalah untuk mengetahui: (1) hasil belajar gambar teknik mesin antara siswa yang diajar dengan strategi pembelajaran Mind Map dan ekspositori, (2) hasil belajar gambar teknik mesin antara siswa yang memiliki gaya belajar visual dengan kinestetik, (3) interaksi antara strategi pembelajaran dan gaya belajar terhadap hasil belajar Gambar teknik mesin. Populasi penelitian ini adalah seluruh siswa kelas X Program keahlian teknik mesin SMK Negeri 2 dan SMK Negeri 5 Medan. Metode penelitian yang menggunakan metode quasi eksperimen dengan desain penelitian faktorial $2 \times 2$. Teknik analisis data menggunakan ANAVA dua jalur pada taraf signifikansi $\alpha=0,05$. Temuan penelitian menunjukkan bahwa: (1) hasil belajar gambar teknik mesin siswa yang diajar dengan strategi pembelajaran Mind Map, lebih tinggi dari pada ekspositori, (2) hasil belajar gambar teknik mesin siswa yang memiliki gaya belajar Kinestetik lebih tinggi daripada gaya belajar Visual, (3) terdapat interaksi antara strategi pembelajaran dan gaya belajar terhadap hasil belajar Gambar teknik mesin. Perhitungan uji lanjut dengan uji Scheffe menunjukkan hasil belajar Gambar teknik mesin siswa yang memiliki gaya belajar kinestetik lebih tinggi bila diajar dengan strategi pembelajaran Mind Map, sedangkan hasil belajar Gambar teknik mesin siswa yang memiliki gaya belajar visual lebih tinggi bila diajar dengan strategi pembelajaran ekspositori.
\end{abstract}

Kata Kunci: strategi pembelajaran mind map dan ekspositori, gaya belajar, gambar teknik mesin

Abstract: The purpose of this study is to determine: (1) the results of studying images of mechanical engineering among students who are taught by learning strategies Mind Map and expository, (2) the results of studying images of mechanical engineering among students who have a visual learning style with kinesthetic, (3) interaction between the learning strategies and learning styles on learning outcomes Figure engineering. The population of this research is all class $X$ students of mechanical engineering expertise program SMK Negeri 2 and SMK Negeri 5 Medan. The research method using quasi-experimental research design $2 \times 2$ factorial ANOVA Analysis using two lanes at significance level $\alpha=0.05$. The findings show that: (1) the results of studying images of mechanical engineering students who are taught by learning strategy Mind Map, higher than in the expository, (2) the results of studying images of mechanical engineering students who have learning style Kinesthetic higher than learning styles Visual, (3) there is no interaction between the learning strategies and learning styles on learning outcomes Figure engineering. Further test calculations with Scheffe test showed learning outcomes Figure engineering students who have a kinesthetic learning style higher when taught by Mind Map instructional strategies, while learning outcomes Picture mechanical engineering students who have a visual learning style higher when taught by expository strategy.

Keywords: learning strategies mind map and expository, learning styles, mechanical engineering drawings

\section{PENDAHULUAN}

SMK Program keahlian teknik mesin itu sendiri adalah salah satu lembaga pendidikan kejuruan teknik yang melaksanakan serangkaian kegiatan belajar yang meliputi berbagai mata pelajaran keteknikan. Adapun mata pelajaran SMK dapat digolongkan dalam tiga golongan, yaitu : mata pelajaran normatif, adaptif, dan produktif. Dari ketiga mata pelajaran ini, mata pelajaran produktif adalah mata pelajaran keahlian yang berhubungan langsung dengan kemampuan keterampilan siswa. Salah satu dari mata pelajaran keahlian 
tersebut terdapat mata pelajaran Menggambar Teknik.

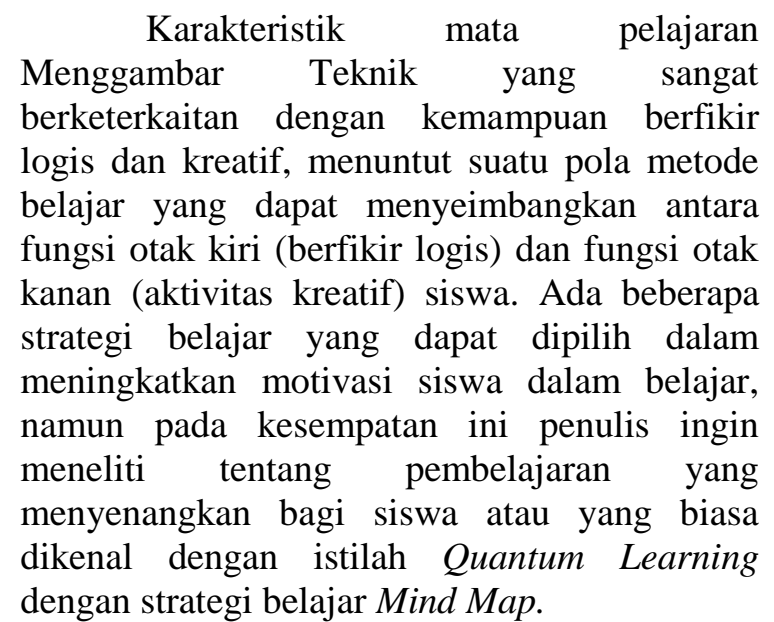
Quantum Learning berupaya memadukan (mengintegrasikan), mensinergikan, dan mengolaborasikan faktor potensi-diri manusia selaku pembelajar dengan lingkungan (fisik dan mental) sebagai konteks pembelajaran. Atau lebih tepat dikatakan di sini bahwa pembelajaran kuantum tidak memisahkan dan tidak membedakan antara res cogitans dan res extenza, antara apa yang di dalam dan apa yang di luar. Dalam pandangan pembelajaran quantum, lingkungan fisikalmental dan kemampuan pikiran atau diri manusia sama-sama pentingnya dan saling mendukung. Karena itu, baik lingkungan maupun kemampuan pikiran atau potensi diri manusia harus diperlakukan sama dan memperoleh stimulan yang seimbang agar pembelajaran berhasil baik. De porter (2007: 169)

Selanjutnya Snellbecker

mengidentifikasi perubahan tingkah laku yang diperoleh melalui belajar dapat dilihat pada ciriciri sebagai berikut: (a) terbentuknya tingkah laku yang baru berupa kemampuan aktual dan potensial: (b) kemampuan ini berlaku dalam waktu yang relatif lama, dan (c) kemampuan baru ini diperoleh melalui usaha. Siswa dalam belajar untuk memperoleh pengetahuan baru, baik melalui penerimaan maupun penemuan keduanya dapat menjadi belajar hafalan atau bermakna dan berhasil dengan baik, maka diperlukan adanya pengaturan kemajuan belajar (advance organizer), yaitu abstraksi dan bahan yang akan dipelajari oleh siswa. Di samping itu agar terjadi proses belajar bermakna, maka dipersyaratkan: (1) bahan pengetahuan yang akan dipelajari harus bermakna secara potensial. (2) siswa yang akan belajar harus bertujuan untuk melaksanakan belajar secara bermakna, sehingga mereka mempunyai kesiapan dan niat untuk belajar secara bermakna (meaningful learning set). Lebih lanjut, dinyatakan bahwa proses belajar siswa dipengaruhi oleh kebermaknaan teknik penyajian, adanya bahan yang relevan dengan struktur kognitif siswa dan keaktifan siswa selama proses pembelajaran.

Gagne (1984) mengatakan belajar adalah suatu perubahan watak (disposition) dan kemampuan (capability) manusia yang berlangsung selama suatu jangka waktu dan tak sekedar menganggapnya proses pertumbuhan. Selanjutnya Gagne mengatakan belajar terjadi apabila suatu situasi stimulus bersama dengan isi ingatan mempengaruhi siswa sedemikian rupa sehingga perbuatan (performance) berubah dari waktu ke waktu selama ia mengalami situasi.

Gambar teknik mesin adalah mata pelajaran gambar di SMK yang mengetengahkan pengetahuan yang paling mendasar dari menggambar teknik itu sendiri yang mencakup: pengenalan akan peralatan dan media gambar dan ketentuan-ketentuan dari standarisasi gambar. Gambar itu sendiri Menurut Sato (2005: 5) Merupakan sebuah alat untuk menyatakan maksud dari seorang penggambar, oleh karena itu gambar sering disebut sebagai "bahasa teknik" atau " bahasa untuk sarjana teknik". Penerusan informasi adalah fungsi yang penting untuk bahasa maupun gambar. Gambar bagaimanapun juga merupakan "bahasa teknik", oleh karena itu diharapkan bahwa gambar harus meneruskan keterangan-keterangan secara tepat dan objektif.

Selain itu Lazzader (2003: 91) menyatakan bahwa: "gambar teknik merupakan suatu sarana yang terpenting untuk melukiskan daya cipta lewat penggunaan garis, Sehingga melalui sebuah gambar, seseorang dapat menangkap dan memahami hal-hal yang terkandung dan direncanakan dalam gambar tersebut". Gambar merupakan suatu hasil pengekspresian ide-ide dari seseorang terhadap suatu objek yang berada di luarnya. Hasil ideide tersebut tertuang pada gambar dalam bentuk sketsa dari objek secara keseluruhan. Menggambar teknik itu sendiri adalah proses mengekspresikan ide-ide suatu objek yang telah ada ataupun sebuah rancangan yang dituangkan dalam bentuk gambar dengan mengikuti kaidah-kaidah menggambar teknik itu sendiri. 
Sehubungan dengan jenis-jenis kemampuan yang merupakan produk hasil belajar yang dikemukakan oleh Bloom di atas, Gagne (1977) mengelompokkan hasil belajar menjadi lima kategori, yaitu: keterampilan intelektual, strategi kognitif, informasi verbal, keterampilan motorik, dan sikap. Kemampuan yang dikemukakan di atas harus sesuai dengan tujuan pembelajaran yang telah ditetapkan. Tiga kategori pertama Gagne yaitu informasi verbal, keterampilan intelektual, dan strategi kognitif dapat disejajarkan dengan ranah kognitif Bloom yang telah direvisi (Anderson, dkk, 2001), yaitu pengetahuan $(\mathrm{C} 1)$, pemahaman $(\mathrm{C} 2)$, penerapan (C3), analisis (C4), evaluasi (C5), dan kreativitas (C6). Hasil belajar dalam penelitian ini mencakup kelima aspek kognitif yang dikemukakan Anderson dkk (2001) di atas, kecuali kreativitas (C6).

Reigeluth (1983) menyatakan bahwa hasil belajar dipengaruhi oleh interaksi antara metode pengajaran dan kondisi pengajaran. Hal-hal yang termasuk metode pengajaran antara lain strategi pengorganisasian, strategi pengelolaan pembelajaran dan penyampaian. Selanjutnya hal-hal yang termasuk kondisi pengajaran adalah karakteristik siswa, karakteristik isi pengajaran, kendala pengajaran, dan berbagai kondisi lain dalam proses pembelajaran. Sedangkan menurut Bloom (1986), ada dua faktor yang sangat berpengaruh terhadap hasil belajar siswa, yaitu kualitas pembelajaran dan karakteristik siswa. Dalam proses penilaian belajar yang berhubungan dengan aspek kognitif biasanya diukur dengan menggunakan tes, sedangkan penilaian hasil belajar yang berhubungan dengan aspek afektif dan keterampilan biasanya diukur dengan alat ukur yang dikategorikan dengan non tes (Nasution dan Suryanto, 2002)

Quantum Learning merupakan model dan falsafah belajar yang terbukti efektif untuk semua umur. Quantum learning berakar dari upaya Lozanov, seorang psikolog yang berupaya mengembangkan prinsip yang disebut "suggestology" atau "suggestopedia. Menurutnya sugesti dapat dan pasti mempengaruhi hasil belajar dan setiap detil keadaan apapun memberikan sugesti positif atau negatif De Porter (1999: 14).

"Strategi pembelajaran adalah suatu kegiatan pembelajaran yang harus dikerjakan guru dan siswa agar tujuan pembelajaran dapat dicapai secara efektif dan efisien. Bahwa dalam strategi pembelajaran terkandung makna perencanaan. Artinya, bahwa strategi pada dasarnya masih bersifat konseptual tentang keputusan-keputusan yang akan diambil dalam suatu pelaksanaan pembelajaran." Akhmad Sudrajat (2008).

Menurut Romizowski (1981) strategi pembelajaran merupakan suatu pendekatan yang dibedakan menjadi dua strategi dasar, yaitu ekspositori (penjelasan) dan inquiri atau diskoveri (penemuan). Kedua strategi ini dapat dipandang sebagai dua ujung yang sejalan dalam suatu kontinum strategi, hal ini erat kaitannya dengan pendekatan deduktif di mana strategi ini dimulai dengan penyajian informasi mengenai prinsip atau kaidah kemudian diikuti dengan tes penguasaan, penerapan dalam bentuk contoh dan penerapan pada situasi tertentu. Sedangkan inquiri atau diskoveri didasarkan pada teori belajar pengalaman yang disebut juga teori belajar pengalaman.

Dick and Carey (2005) menyatakan bahwa strategi pembelajaran merupakan komponen umum dari bahan pembelajaran dan prosedur yang akan digunakan untuk menghasilkan suatu hasil belajar pada siswa, yang berkenaan dengan strategi pembelajaran untuk menyampaikan materi secara sistematik sehingga kemampuan yang diharapkan dapat dikuasai secara efektif dan efisien. Lebih lanjut Carey (2005) menjelaskan bahwa ada 5 (lima) komponen strategi pembelajaran: (1) prainstruksional, yang meliputi: memotivasi siswa, deskripsi materi, dan analisis perilaku awal; (2) penyajian informasi, yang meliputi: penjelasan tujuan pembelajaran, uraian isi materi dan contoh; (3) partisipasi siswa, yang meliputi: latihan dan umpan balik; (4) penilaian (tes), yang meliputi: tes perilaku awal, pretes, dan protes; dan (5) tindak lanjut, yang meliputi: bantuan kesan untuk ingatan dan pertimbangan.

Sementara itu, Gerlach dan Erly (1980) mendefinisikan bahwa strategi pembelajaran merupakan semua metode mengajar yang dapat dipakai guru untuk menyampaikan materi, mulai dari ekspositori sampai ke metode discovery dan tugas guru adalah memilih strategi pembelajaran tersebut untuk menyampaikan materi. Sementara itu, Uno (2008: 45) berpendapat bahwa strategi pembelajaran merupakan hal yang perlu diperhatikan guru dalam proses pembelajaran. Paling tidak ada tiga jenis strategi pembelajaran, yakni: (1) strategi pengorganisasian pembelajaran, (2) strategi 
penyampaian pembelajaran, dan (3) strategi pengelolaan pembelajaran.

Mind Map menurut Sutanto (2008: 16) adalah suatu teknik grafis yang memungkinkan kita untuk mengeksplorasi seluruh kemampuan otak kita untuk keperluan berfikir dan belajar.

Menurut Sutanto (2008: 16) Otak manusia secara fungsional dibagi ke dalam dua bagian yaitu otak kanan dan otak kiri. Otak kiri akan berkaitan dengan kata, angka, analisa, logika, urutan, hitungan dan detil. Sedangkan otak kanan berkaitan dengan gambar, warna, irama, gestalt dimensi, imajinasi, dan melamun.

Sedangkan menurut Sutanto (2008: 2):

"Whole Brain Thinking adalah suatu terobosan cara berpikir dengan memanfaatkan dua belahan otak secara sinergis. Mind mapping atau pemetaan pikiran merupakan salah satu teknik mencatat tinggi." Informasi berupa materi pelajaran yang diterima siswa dapat diingat dengan bantuan catatan. Peta pikiran merupakan bentuk catatan yang tidak monoton karena Mind mapping memadukan fungsi kerja otak secara bersamaan dan saling berkaitan satu sama lain. Sehingga akan terjadi keseimbangan kerja kedua belahan otak. Otak dapat menerima informasi berupa gambar, simbol, citra, musik dan lain-lain yang berhubungan dengan fungsi kerja otak kanan.

Sanjaya (2009: 179) mengemukakan bahwa strategi pembelajaran Ekspositori adalah strategi pembelajaran yang menekankan kepada proses penyampaian materi secara verbal dari seorang guru kepada sekelompok siswa dengan maksud agar siswa dapat menguasai materi pelajaran secara optimal. Killen dalam Sanjaya (2009) menamakan strategi Ekspositori ini dengan istilah strategi pembelajaran langsung (direct instruction). Oleh karena strategi ekspositori lebih menekankan kepada proses bertutur, maka sering juga dinamakan dengan istilah strategi "chalk and talk".

Terdapat beberapa karakteristik pada strategi pembelajaran Ekspositori (Sanjaya, 2009: 179) yaitu seperti berikut ini : (1) Strategi Ekspositori dilakukan dengan cara menyampaikan materi pelajaran secara verbal, artinya bertutur lisan merupakan alat utama dalam melakukan strategi ini, oleh karena itu orang sering mengidentikkannya dengan ceramah.(2) Biasanya materi pelajaran yang disampaikan adalah materi pelajaran yang sudah jadi, seperti data atau fakta, konsepkonsep tertentu yang sudah dihafal sehingga tidak menuntut siswa untuk berfikir ulang. (3)
Tujuan utama pembelajaran adalah penguasaan materi pelajaran itu sendiri. Artinya, setelah proses pembelajaran berakhir siswa diharapkan dapat memahaminya dengan benar dengan cara dapat menggungkapkan kembali materi yang telah diuraikan.

Howard Gardner (1983) dalam bukunya The Theory of Multiple Intelegence, mengusulkan tujuh macam komponen kecerdasan, yang disebutnya dengan Multiple Intelegence (Intelegensi Ganda). Intelegensi ganda meliputi: (1) kecerdasan linguistic-verbal dan (2) kecerdasan logiko-matematik yang sudah dikenal sebelumnya, ia menambahkan dengan komponen kecerdasan lainnya yaitu (3) kecerdasan spasial-visual, (4) kecerdasan ritmik-musik, (5) kecerdasan kinestetik, (6) kecerdasan interpersonal, (7) kecerdasan intrapersonal. Sekarang tujuh kecerdasan tersebut di atas sudah bertambah lagi dengan satu komponen kecerdasan yang lain, yaitu (8) kecerdasan naturalis.

Kemudian De Porter (2008: 110) mengatakan gaya belajar merupakan cara yang cenderung dipilih seseorang untuk menerima informasi dari lingkungan dan memproses informasi tersebut. Dalam hal belajar, masingmasing individu memiliki kelebihan dan kekurangan dalam menyerap pelajaran yang diberikan. Oleh karena itu dalam dunia pendidikan dikenal berbagai metode yang dapat dipergunakan guru untuk dapat memenuhi tuntutan perbedaan individu tersebut. Guru membutuhkan rancangan desain pembelajaran untuk menjembatani hubungan antara siswa dengan guru sesuai dengan gaya belajarnya.

Olivia (2008: 2) mengatakan bahwa tidak ada gaya belajar yang lebih baik dari yang lain, karena ketiga gaya belajar ini dimiliki oleh setiap orang. Hanya saja ada salah satu gaya belajar yang lebih dominan pada diri kita. Jadi, bila seseorang belajar sesuai dengan gaya belajarnya yang dominan, pelajaran akan lebih mudah diterima dan kemungkinan suksesnya juga lebih tinggi.

Menurut DePorter (2007: 165) ada beberapa gaya belajar lainnya yang bisa dipilih untuk belajar secara efektif. Beberapa gaya belajar yang mungkin terdapat pada anak didik yakni gaya belajar Auditorial, gaya belajar Kinestetik, dan gaya belajar Visual. Mengamati tingkah laku anak sehari-hari, terutama saat mereka bermain, adalah cara yang paling efektif mengamati kecenderungan gaya belajar anak. Sesuai dengan karakteristik pembelajaran 
menggambar teknik yang cenderung pada ranah psikomotorik, gaya belajar yang akan diteliti akan dibatasi hanya pada gaya belajar visual dan kinestetik. Di bawah ini terdapat panduan untuk mengamati tingkah laku anak dan melihat kecenderungan gaya belajar mereka menurut gaya belajar V-K (Visual, atau Kinesthetics). Panduan untuk mengamati tingkah laku anak dan melihat kecenderungan gaya belajar mereka menurut model gaya belajar V-K (Visual dan Kinesthetik).

Gaya Belajar Kinestetik Ciri-ciri perilaku yang merupakan petunjuk bagi individu yang memiliki gaya belajar secara Kinestetik (DePorter, 2007: 168): (1) berbicara dengan lambat; (2) terbiasa menyentuh orang lain untuk mendapatkan perhatian; (3)terbiasa berdiri dekat-dekat dengan lawan bicara 4) berorientasi pada fisik dan banyak bergerak; (5) belajar melalui manipulasi dan praktek; (6) terbiasa menghafal dengan berjalan dan melihat; (7) membaca dengan menggunakan jari untuk menunjuk; (8) banyak menggunakan isyarat tubuh; (9) tidak dapat duduk dengan tenang pada waktu yang lama; 10) membuat keputusan berdasarkan perasaan; (11) kebiasaan mengetuk-ngetuk pena, jari, atau kaki saat mendengarkan; (12) banyak meluangkan waktu untuk berolah raga dan kegiatan fisik lainnya.

Gaya Belajar Visual adalah Individu yang memiliki gaya belajar visual yang baik ditandai dengan ciri-ciri perilaku sebagai berikut, DePorter (2000: 116): (1) rapi dan teratur; (2) berbicara dengan cepat; 3) mampu membuat rencana jangka pendek dengan baik; (4) teliti dan rinci; (5) mementingkan penampilan; (6) lebih mudah mengingat apa yang akan dilihat daripada apa yang didengar; (7) mengingat sesuatu berdasarkan asosiasi visual; (8) memiliki kemampuan mengeja huruf dengan sangat baik; (9) biasanya tidak mudah terganggu oleh keributan atau suara berisik ketika sedang belajar; (10) sulit menerima instruksi verbal (oleh karena itu seringakali ia minta instruksi secara tertulis; (11) merupakan pembaca yang cepat dan tekun (12) lebih suka membaca daripada dibacakan; (13) suka membuat coretan-coretan tanpa arti ketika sedang bertelepon atau menghadiri rapat; (14) lebih suka mendemontrasikan sesuatu dari pada berpidato/berceramah; (15) lebih tertarik pada bidang seni (lukisan, pahat, gambar) dari pada musik, dan (16) sering tahu apa yang dikatakan, tetapi tidak pandai menuliskan dalam kata-kata.
Rumusan masalah pada penelitian ini adalah: (1) Apakah hasil belajar siswa yang menggunakan strategi pembelajaran Mind Map lebih tinggi dari hasil belajar siswa yang diajar dengan strategi pembelajaran ekspositori ?; (2) Apakah hasil belajar siswa yang memiliki gaya belajar Kinestetik lebih tinggi dari pada hasil belajar siswa yang memiliki gaya belajar Visual dalam mata pelajaran gambar teknik mesin?; (3) Apakah terdapat interaksi antara strategi pembelajaran dengan dengan gaya belajar dalam mempengaruhi hasil belajar gambar teknik mesin?. Adapun hipotesis sebagai berikut ini, yaitu: (1) Hasil belajar Gambar teknik mesin siswa yang diajarkan dengan dengan strategi Mind Map lebih tinggi dibandingkan hasil belajar siswa yang diajar dengan strategi pembelajaran Ekspositori; (2) Hasil belajar gambar teknik mesin siswa yang memiliki gaya belajar Kinestetik lebih tinggi dari pada hasil belajar siswa yang memiliki gaya belajar Visual; dan (3) Terdapat interaksi antara Strategi Pembelajaran dan Gaya Belajar terhadap hasil belajar gambar teknik mesin Siswa.

\section{METODE}

Penelitian in dilaksanakan di SMK Negeri 2 dan SMK Negeri 5 Medan Populasi dalam penelitian ini adalah siswa SMK Negeri 2 Medan kelas $X$ Program keahlian teknik mesin dan siswa SMK Negeri 5 Medan kelas X Program keahlian teknik mesin dan Paket keahlian teknik pemesinan. Teknik pengambilan sampel dilakukan dengan teknik cluster random sampling, selanjutnya melalui pengundian maka SMK Negeri 2 Medan kelas $\mathrm{X}$ Program keahlian teknik mesin sebagai kelas yang diberi perlakuan dengan strategi pembelajaran Mind Map (kelas eksprimen) dan Negeri 5 Medan kelas X Program keahlian teknik mesin terpilih sebagai kelas yang diberi perlakuan dengan strategi pembelajaran ekspositori. Sebelum dilakukan eksperimen, kedua kelas sampel terlebih dahulu diberi tes untuk mengetahui gaya belajar siswa. Gaya belajar dikategorikan atas gaya belajar kinestetik dan gaya belajar visual.

Penelitian ini menggunakan metode eksperimental semu (quasi-experimental design) dengan melakukan eksperimen di dalam kelas yang sudah tersedia sebagaimana adanya, tanpa melakukan perubahan situasi kelas dan jadwal pembelajaran (kelas yang intaks). Perlakuan dilaksanakan pada pembelajaran 
Gambar teknik mesin dengan menggunakan strategi pembelajaran Mind Map yang dibandingkan dengan strategi pembelajaran ekspositori dan dilaksanakan pada kelas perlakuan yang telah ditetapkan. Pada masingmasing kelas terdapat siswa yang memiliki gaya belajar kinestetik dan gaya belajar visual berdasarkan hasil analisis skor tes gaya belajar menurut De Porter (2008) yang telah baku dan disusun dengan menggunakan indikatorindikator yang telah standar. Guru yang ditetapkan untuk melakukan pembelajaran dengan strategi Mind Map maupun ekspositori diberikan petunjuk khusus mengenai cara dan langkah-langkah dalam penyajian materi pelajaran.

Desain penelitian yang digunakan adalah desain faktorial $2 \times 2$, seperti terlihat pada Tabel 1. yang mengelompokkan strategi Mind Map dengan strategi pembelajaran ekspositori terhadap gaya belajar visual dan gaya belajar kinestetik.

Tabel 1. Desain Faktorial 2 x 2

\begin{tabular}{|l|c|c|}
\hline Sembelajaran $(\mathrm{A})$ & Mind Map $\left(\mathrm{A}_{1}\right)$ & Ekspositori $\left(\mathrm{A}_{2}\right)$ \\
Gaya belajar (B) & $\mathrm{A}_{1} \mathrm{~B}_{1}$ & $\mathrm{~A}_{2} \mathrm{~B}_{1}$ \\
\hline Kinestetik $\left(\mathrm{B}_{1}\right)$ & $\mathrm{A}_{1} \mathrm{~B}_{2}$ & $\mathrm{~A}_{2} \mathrm{~B}_{2}$ \\
\hline Visual $\left(\mathrm{B}_{2}\right)$ & \\
\hline
\end{tabular}

Teknik pengumpulan data dalam penelitian ini adalah menggunakan tes untuk hasil belajar Gambar teknik mesin dan tes gaya belajar siswa. Tes hasil belajar berupa pertanyaan-pertanyaan dalam bentuk pilihan ganda dengan 4 (empat) pilihan jawaban pada mata pelajaran Gambar teknik mesin SMK Program keahlian teknik mesin yang meliputi materi ajar standar gambar teknik, memilih dan menentukan peralatan, perlengkapan dan media gambar sesuai dengan tujuan penggambaran, Macam-macam penggaris, Satuan dasar dan skala gambar, sedangkan untuk mengelompokkan siswa atas gaya belajar visual maupun kinestetik dilaksanakan dengan tes gaya belajar menurut De Porter (2008).

Teknik analisis data dalam penelitian ini menggunakan analisis deskriptif dan analisis inferensial. Teknik analisis deskriptif dimaksudkan untuk mendeskripsikan data penelitian meliputi mean, median, standard deviasi dan kecenderungan data. Data yang telah diperoleh selanjutnya disajikan dalam bentuk tabel distribusi frekuensi dan histogram. Teknik analisis inferensial digunakan untuk menguji hipotesis penelitian dengan menggunakan teknik analisis varians (ANAVA) dua jalur. Untuk menggunakan ANAVA dua jalur perlu dipenuhi beberapa syarat yaitu: (1) data yang digunakan harus berdistribusi normal, untuk menguji normalitas data digunakan uji Liliefors, dan (2) data harus memiliki varians populasi homogen, untuk menguji homogenitas varians digunakan uji $\mathrm{F}$ (Fisher) dan

Rumusan hipotesis statistik dalam penelitian ini adalah sebagai berikut:

a. Hipotesis pertama :

$$
\begin{array}{ll}
\text { Ho } & : \mu_{A 1} \leq \mu_{A 2} \\
\text { H1 } & : \mu_{A 1}>\mu_{A 2}
\end{array}
$$

b. Hipotesis kedua :

$$
\begin{array}{ll}
\text { Ho } & : \mu_{B 1} \leq \mu_{B 2} \\
\text { H1 } & : \mu_{B 1}>\mu_{B 2}
\end{array}
$$

c. Hipotesis ketiga :

Ho : $\mathrm{A} \times \mathrm{B}=0$

\section{HASIL PENELITIAN}

Rangkuman data tersebut dapat dilihat pada Tabel 2 dengan menggunakan analisis deskriptif.

Tabel 2. Rangkuman Data Hasil Perhitungan Analisis Deskriptif. 


\begin{tabular}{|c|c|c|c|c|c|c|c|}
\hline \multirow{2}{*}{\multicolumn{2}{|c|}{$\mathrm{GB}_{\mathrm{GP}}^{\mathrm{SP}}$}} & \multicolumn{4}{|c|}{ Strategi Pembelajaran } & & \multirow{2}{*}{ Total } \\
\hline & & & nd Map & & kspositori & & \\
\hline \multirow{2}{*}{ 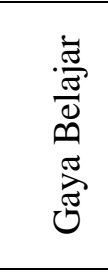 } & Kinestetik & $\begin{array}{l}\mathrm{n} \\
\overline{\mathrm{X}} \\
\mathrm{Sd}\end{array}$ & $\begin{array}{l}=11 \\
=30.64 \\
=3.14\end{array}$ & $\frac{\mathrm{n}}{\mathrm{X}}$ & $\begin{array}{l}=12 \\
=24.83 \\
=4.06\end{array}$ & $\begin{array}{l}\mathrm{n} \\
\mathrm{X} \\
\mathrm{Sd}\end{array}$ & $\begin{array}{l}=23 \\
=27.61 \\
=4.66\end{array}$ \\
\hline & Visual & & $\begin{array}{l}=13 \\
=23.31 \\
=3.79\end{array}$ & $\begin{array}{l}\mathrm{n} \\
\overline{\mathrm{X}} \\
\mathrm{Sd}\end{array}$ & $\begin{array}{l}=13 \\
=23.69 \\
=3.47\end{array}$ & $\begin{array}{l}\mathrm{n} \\
\mathrm{X} \\
\mathrm{Sd}\end{array}$ & $\begin{array}{l}=26 \\
=23,50 \\
=3.65\end{array}$ \\
\hline \multicolumn{2}{|c|}{ Total } & & $\begin{array}{l}=24 \\
=26.67 \\
=5.06\end{array}$ & & $\begin{array}{l}=25 \\
=24.24 \\
=3.81\end{array}$ & $\begin{array}{l}\mathrm{n} \\
\bar{X} \\
\mathrm{Sd}\end{array}$ & $\begin{array}{l}=49 \\
=25.42 \\
=4.62\end{array}$ \\
\hline
\end{tabular}

Setelah data tabel 2 diolah dengan ANAVA 2 jalur faktorial 2 x 2, maka diperoleh hasil analisis seperti ditunjukkan pada Tabel 3 .

Tabel 3. Ringkasan Perhitungan ANAVA Faktorial 2x2

\begin{tabular}{|c|c|c|c|c|c|}
\hline Sumber variasi & $\mathrm{dk}$ & $\mathrm{JK}$ & RJK & $F_{\text {hitung }}$ & $\begin{array}{c}\mathrm{F}_{\text {tabel }(1.45)} \\
(\alpha=0.05)\end{array}$ \\
\hline Strategi Pembelajaran & 1 & 206,02 & 206,02 & 14,27 & 4.05 \\
\hline Gaya Belajar & 1 & 72,12 & 72,12 & 4,99 & \\
\hline Interaksi & 1 & 122,11 & 122,11 & 8,46 & \\
\hline Galat & 45 & 649,75 & 14.44 & & \\
\hline Total & 48 & 1050 & & & \\
\hline
\end{tabular}

Pada tabel ringkasan ANAVA untuk strategi pembelajaran diperoleh $\mathrm{F}_{\text {hitung }}=14,27>$ $\mathrm{F}_{\text {tabel }}=4.05$, untuk gaya belajar $\mathrm{F}_{\text {hitung }}=4,99>$ $\mathrm{F}_{\text {tabel }}=4.05$ dan untuk interaksi diperoleh $\mathrm{F}_{\text {hitung }}$ $=8,46>\mathrm{F}_{\text {tabel }}=4.05$ berdasarkan data-data tersebut, dapat disimpulkan adanya interaksi antara strategi pembelajaran dengan gaya belajar yang mempengaruhi hasil belajar gambar teknik mesin siswa.

Perbedaan Hasil Belajar Gambar teknik mesin Antara Siswa yang Diajar dengan Strategi Mind Map dan Strategi Pembelajaran Ekspositori

Pengujian dilakukan terhadap hipotesis statistik yang dirumuskan sebagai berikut:

Ho: $: \mu_{P_{12}} \leq \mu_{P_{34}} \quad ; \quad H a: \mu_{P_{12}}>\mu_{P_{34}}$

Pernyataan hipotesis tersebut adalah :

Ho = Tidak terdapat perbedaan hasil belajar gambar teknik mesin antara siswa yang diajar dengan strategi Mind Map dengan siswa yang diajar dengan strategi pembelajaran Ekspositori

$\mathrm{Ha}=$ Siswa yang diajar dengan strategi Mind Map memperoleh hasil belajar gambar teknik mesin lebih tinggi daripada siswa yang diajar dengan strategi pembelajaran ekspositori.
Dari hasil perhitungan analisis tentang perbedaan hasil belajar gambar teknik mesin siswa yang diajar dengan strategi Mind Map sebesar $\overline{\mathrm{X}}=26,67$ dan strategi pembelajaran ekspositori $\overline{\mathrm{X}}=24,24$, didapat hasil perhitungan $F_{h}$ sebesar 14,27 dan harga tabel $F_{t}$ adalah 4.05. Dengan demikian temuan penelitian menyimpulkan, bahwa hipotesis penelitian yang menyatakan: hasil belajar gambar teknik mesin siswa yang diajar dengan strategi Mind Map lebih tinggi daripada hasil belajar gambar teknik mesin siswa yang diajar dengan strategi pembelajaran ekspositori pada taraf kepercayaan $\alpha=0,05$ telah teruji kebenarannya.

Perbedaan Hasil Belajar Gambar teknik mesin Antara Siswa dengan Gaya Belajar Kinestetik dan Gaya Belajar Visual.

Pengujian dilakukan terhadap hipotesis statistik yang dirumuskan sebagai berikut:

$$
\text { Ho: } \mu_{P_{13}} \leq \mu_{P_{24}} \quad ; \quad H a: \mu_{P_{13}}>\mu_{P_{24}}
$$

Pernyataan hipotesis tersebut adalah :

$\mathrm{H}_{0}=$ Tidak Terdapat perbedaan hasil belajar gambar teknik mesin antara siswa yang memiliki gaya belajar kinestetik dengan siswa yang memiliki gaya belajar visual 
$\mathrm{Ha}=$ Hasil belajar gambar teknik mesin siswa yang memiliki gaya belajar kinestetik lebih tinggi daripada hasil belajar gambar teknik mesin siswa yang memiliki gaya belajar visual Hasil perhitungan analisis varian tentang perbedaan hasil belajar gambar teknik mesin antara siswa yang memiliki gaya belajar kinestetik dengan rata-rata $\bar{X}=27,61$ dan gaya belajar visual $\bar{X}=23,5$. Dapat dihitung $F_{h}=$ 4,99 dan harga tabel untuk $\alpha=0,05$ dengan $\mathrm{dk}$ (1) diperoleh $F_{t}=4.05$ sehingga dapat dinyatakan $F_{h}(4,99)>F_{t}(4.05)$. Dengan demikian temuan penelitian menyimpulkan hipotesis penelitian yang menyatakan: hasil belajar gambar teknik mesin siswa yang memiliki gaya belajar kinestetik lebih tinggi daripada hasil belajar siswa yang memiliki gaya belajar visual pada taraf kepercayaan $\alpha=0,05$ telah teruji kebenarannya.

\section{Interaksi Antara Strategi Pembelajaran dan Gaya Belajar Terhadap Hasil Belajar Gambar teknik mesin Siswa}

Pengujian dilakukan terhadap hipotesis statistik yang dirumuskan sebagai berikut :

Ho: Interaksi $(\mathrm{B}$ x T $)=0 \quad ; \quad$ Ha: Interaksi $(\mathrm{B}$ x T $) \neq 0$
Pernyataan hipotesis tersebut adalah :

Ho = Tidak terdapat interaksi antara strategi pembelajaran dan gaya belajar terhadap hasil belajar gambar teknik mesin siswa.

$\mathrm{Ha}=$ Terdapat interaksi antara strategi pembelajaran dan gaya belajar terhadap hasil belajar gambar teknik mesin siswa.

Berdasarkan hasil perhitungan ANAVA faktorial $2 \times 2$ diperoleh hasil perhitungan $\mathrm{F}_{\mathrm{h}}=$ 8,46 dengan harga tabel $F_{t}$ untuk taraf kepercayaan $(\alpha)$ sebesar 0,05 dengan $\mathrm{dk}=1$ adalah $\mathrm{F}_{\mathrm{t}}=4.05$ sehingga dapat dinyatakan $\mathrm{F}_{\mathrm{h}}$ $(8,46)>F_{t}(4.05)$, dengan demikian dapat disimpulkan pernyataan hipotesis penelitian yang menyatakan: terdapat interaksi antara Strategi pembelajaran dan gaya belajar terhadap hasil belajar gambar teknik mesin siswa telah teruji kebenarannya pada taraf signifikan $\alpha=$ 0,05 .

Data yang diperoleh dalam penelitian ini berasal dari sampel yang jumlahnya berbeda untuk setiap sel Anava. Sehingga perlu dilakukan uji Schefee, hasil pengujian dengan menggunakan uji Scheffee dapat dilihat dalam Tabel 4.

Tabel 4. Ringkasan Hasil Pengujian Dengan Menggunakan Uji Scheffe

\begin{tabular}{|c|c|c|c|}
\hline \multicolumn{2}{|c|}{ Hipotesis Statistik } & \multirow{2}{*}{ F $_{\text {hitung }}$} & $\mathbf{F}_{\text {tabel }}$ \\
\cline { 3 - 4 } & $\boldsymbol{\alpha}=\mathbf{5 \%}$ \\
\hline Ho $: \mu \mathrm{A}_{1} \mathrm{~B}_{1}=\mu \mathrm{A}_{2} \mathrm{~B}_{1}$ & Ho $: \mu \mathrm{A}_{1} \mathrm{~B}_{1}>\mu \mathrm{A}_{2} \mathrm{~B}_{1}$ & 3.66 & 2.81 \\
\hline Ho $: \mu \mathrm{A}_{1} \mathrm{~B}_{2}=\mu \mathrm{A}_{2} \mathrm{~B}_{2}$ & Ho $: \mu \mathrm{A}_{1} \mathrm{~B}_{2}>\mu \mathrm{A}_{2} \mathrm{~B}_{2}$ & 0.26 & 2.81 \\
\hline Ho $: \mu \mathrm{A}_{1} \mathrm{~B}_{1}=\mu \mathrm{A}_{1} \mathrm{~B}_{2}$ & Ho $: \mu \mathrm{A}_{1} \mathrm{~B}_{1}>\mu \mathrm{A}_{1} \mathrm{~B}_{2}$ & 4.71 & 2.81 \\
\hline Ho $: \mu \mathrm{A}_{2} \mathrm{~B}_{1}=\mu \mathrm{A}_{2} \mathrm{~B}_{2}$ & Ho $: \mu \mathrm{A}_{2} \mathrm{~B}_{1}>\mu \mathrm{A}_{2} \mathrm{~B}_{2}$ & 0.75 & 2.81 \\
\hline Ho $: \mu \mathrm{A}_{1} \mathrm{~B}_{1}=\mu \mathrm{A}_{2} \mathrm{~B}_{2}$ & Ho $: \mu \mathrm{A}_{1} \mathrm{~B}_{1}>\mu \mathrm{A}_{2} \mathrm{~B}_{2}$ & 4.46 & 2.81 \\
\hline Ho $: \mu \mathrm{A}_{2} \mathrm{~B}_{1}=\mu \mathrm{A}_{1} \mathrm{~B}_{2}$ & Ho $: \mu \mathrm{A}_{2} \mathrm{~B}_{1}>\mu \mathrm{A}_{1} \mathrm{~B}_{2}$ & 0.99 & 2.81 \\
\hline
\end{tabular}

Hasil pengujian hipotesis di atas, menunjukkan adanya interaksi antara strategi pembelajaran dan gaya belajar terhadap hasil belajar gambar teknik mesin. 


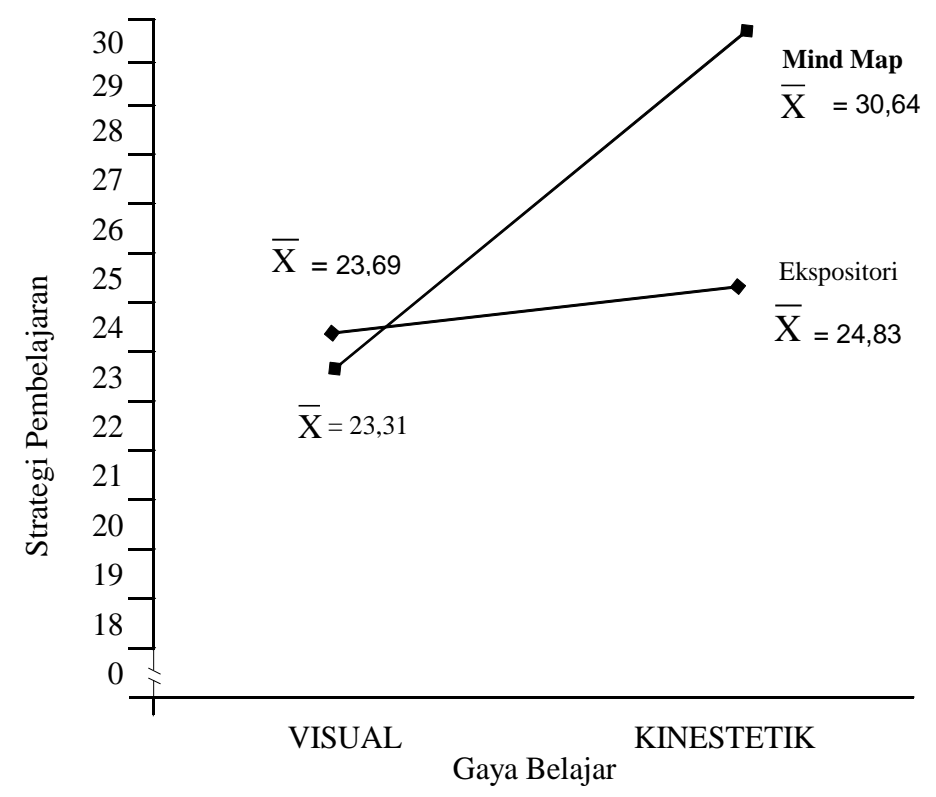

Gambar 1. Interaksi Strategi Pembelajaran dan Gaya Belajar terhadap Hasil Belajar Gambar teknik mesin.

\section{PEMBAHASAN}

Strategi Mind Map memberikan hasil yang lebih baik karena strategi ini menggunakan prinsip manajemen otak untuk membuka seluruh potensi dan kapasitas otak yang masih tersembunyi. Disatu sisi selama ini siswa hanya mendapatkan what to learn dari pendidikan formalnya, yaitu materi pelajaran yang diberikan oleh guru, sementara di sisi lain penguasaan how to learn juga mutlak dibutuhkan oleh siswa namun jarang diberikan atau malah tidak diperoleh sama sekali dalam proses pembelajaran. Ketidakseimbangan aspek inilah yang menyebabkan belajar bukanlah aktivitas yang menyenangkan bagi siswa. Hasilnya, siswa tidak dapat menunjukkan kemampuan terbaik otaknya dalam prestasi akademiknya.

Srtategi pembelajaran Mind Map merupakan bagian pembelajaran kuantum (Quantum Teaching-Learning) yang berasal dari teori pembelajaran konstruktivisme kognitif dengan menekankan kemampuan siswa untuk membangun sendiri pengetahuan di dalam benaknya dan peran guru bukan hanya sekedar memberikan pengetahuan kepada siswa melainkan memberikan kemudahan belajar (how to learn) pada siswa dengan memberikan kesempatan kepada siswa untuk menemukan atau menerapkan ide-ide mereka sendiri. Pembelajaran kuantum memiliki pandangan tertentu tentang pembelajaran dan pembelajar De Porter, dkk (1999) diantaranya : 1) Pembelajaran berlangsung secara aktif karena pebelajar itu aktif dan kreatif. Bukti keaktifan dan kekreatifan itu dapat ditemukan dalam peranan dan fungsi otak kanan dan otak kiri pembelajar. Pembelajaran pasif mengingkari kenyataan bahwa pembelajar itu aktif dan kreatif, mengingkari peranan dan fungsi otak kanan dan otak kiri. 2) Pembelajaran berlangsung efektif dan optimal bila didasarkan pada karakteristik gaya belajar pembelajar sehingga penting sekali pemahaman atas gaya belajar pembelajar. Setidak-tidaknya ada tiga gaya belajar yang harus diperhitungkan dalam proses pembelajaran, yaitu gaya auditoris, gaya visual, dan gaya kinestetis 3) Pembelajaran terutama pengajaran membutuhkan keserasian konteks dan isi. Segala konteks pembelajaran perlu dikembangkan secara serasi dengan isi pembelajaran. Untuk itulah harus diciptakan dan dipelihara suasana yang memberdayakan atau menggairahkan, landasan yang kukuh, lingkungan fisikal-mental yang mendukung, dan rancangan pembelajaran yang dinamis. Selain itu, perlu juga diciptakan dan dipelihara penyajian yang prima, pemfasilitasan yang lentur, keterampilan belajar yang merangsang untuk belajar, dan keterampilan hidup yang suportif. 
Hasil penelitian menunjukkan bahwa rata-rata hasil belajar gambar teknik mesin siswa yang memiliki gaya belajar kinestetik lebih tinggi daripada hasil belajar gambar teknik mesin siswa yang memiliki gaya belajar visual. Selanjutnya dalam penelitian ini juga terbukti bahwa hasil belajar gambar teknik mesin siswa yang memiliki gaya belajar kinestetik yang diajar dengan Strategi pembelajaran Mind Map lebih tinggi daripada hasil belajar gambar teknik mesin siswa yang diajar dengan Strategi pembelajaran ekspositori. Hal ini mengindikasikan bahwa siswa yang mempunyai gaya belajar kinestetik lebih mampu memahami bahan pelajaran gambar teknik mesin denagn cara Mind Map dibandingkan siswa yang mempunyai gaya belajar visual. Penelitian ini juga membuktikan bahwa siswa yang memiliki gaya belajar kinestetik lebih cocok diajar dengan menggunakan Strategi Mind Map. Pembelajaran dengan Strategi Mind Map sangat tepat dibandingkan Strategi pembelajaran ekspositori untuk diterapkan pada siswa yang memiliki gaya belajar kinestetik.

Temuan penelitian menunjukkan bahwa terdapat interaksi antara Strategi pembelajaran dan gaya belajar terhadap hasil belajar gambar teknik mesin siswa. Siswa yang memiliki gaya belajar kinestetik yang diajar dengan Strategi Mind Map lebih tinggi hasil belajar menggambar tekniknya daripada siswa yang memiliki gaya belajar visual yang diajar dengan Strategi Mind Map. Demikian pula siswa yang memiliki gaya belajar sekuensial abstrak yang diajar dengan Strategi pembelajaran ekspositori memperoleh hasil belajar gambar teknik mesin yang lebih tinggi daripada siswa yang memiliki gaya belajar kinestetik dengan Strategi pembelajaran ekspositori. Hal ini mengindikasikan adanya interaksi antara Strategi pembelajaran dengan gaya belajar terhadap hasil belajar gambar teknik mesin siswa.

Strategi pembelajaran Mind Map merupakan pendekatan pembelajaaran yang menuntut adanya interaksi dua arah antara guru dan siswa, serta siswa dengan siswa. Siswa diberi tugas untuk memecahkan persoalan gambar teknik mesin dalam konteks kehidupan nyata dangan kegiatan yang menyenangkan namun serius dalam pemerolehan berbegai konsep yang akan ditemukan. Dengan jalan ini siswa yang memiliki gaya belajar kinestetik akan lebih lebih terpacu untuk menemukan ide- ide atau gagasan-gagasan yang lebih relevan dalam rangka menyelesaikan langkah-langkah kerja dan memecahkan berbagai persoalan dan isu yang dikemukakan. Pada siswa yang memiliki gaya belajar kinestetik adanya variasi dalam kegiatan pendahuluan hingga kegiatan penutup yang sengaja dikondisikan guru secara bermakna, akan memudahkan siswa untuk memahami materi pelajaran gambar teknik mesin. Selain itu pola pikir realistik dan kemampuan bekerjasama yang lebih tinggi yang dimiliki oleh siswa yang berpikir sekunsial konkrit akan memudahkan mereka dalam belajar.

Hasil belajar yang optimal akan diperoleh apabila beragam perbedaan seperti kebiasaan, minat, gaya belajar, dan kreatifitas pada peserta didik diakomodasi oleh guru melalui pilihan strategi pembelajaran dan materi ajar yang sesuai. Pembelajaran bidang studi apapun, bisa ditingkatkan kualitasnya, apabila guru memahami karakteristik peserta didik dengan baik termasuk gaya belajarnya. Kemudian, informasi tentang peserta didik tersebut menjadi bahan pertimbangan bagi guru dalam memilih strategi dan materi ajar yang sesuai dengan keberagaman potensi peserta didik.

Strategi pembelajaran Mind Map menciptakan adanya keseimbangan kerja antara kedua belahan otak siswa dalam proses merangkum informasi yang diterima oleh. Dalam strategi ini siswa akan dibawa uatuk membangun sebuah gambaran dan pemahaman secara pribadi dengan daya kreatifitas yang mereka ciptakan sendiri. Dalam hal ini guru berperan dalam melengkapi dan merangsang siswa untuk membangun pemahaman dengan informasi yang lebih konprehensif.

Strategi Mind Map menuntut tanggung jawab sekaligus keleluasaan dan kebebasan mengembangkan kreatifitas dalam belajar. Sedangkan dalam strategi pembelajaran ekspositori siswa dituntut untuk mampu memahami materi pelajaran terhadap materi dalam bentuk lisan dan hafalan. Strategi ekspositori membiasakan siswa belajar melalui buku dan guru. Sedangkan lingkungan yang mestinya menjadi sumber pembelajaran sosial tidak memiliki peran dalam meningkatkan pemahaman siswa terhadap materi pelajaran. Hal ini sangat bertolak belakang dengan strategi Mind Map yang memiliki kukuatan pembelajaran dari menganalisis masalah yang 
timbul di lingkungan sekitar dengan teori yang diperoleh di kelas.

Oleh karena itu berdasarkan pemaparan di atas dapat dipahami bahwa interaksi antara strategi pembelajaran dengan gaya belajar dalam mempengaruhi hasil belajar gambar teknik mesin terjadi pada siswa yang memiliki gaya belajar kinestetik. Artinya siswa dengan gaya belajar kinestetik akan memperoleh hasil belajar yang lebih tinggi dan signifikan jika dibelajarkan dengan strategi Mind Map daripada dibelajarkan dengan strategi ekspositori. Sedangkan siswa dengan gaya belajar visual meskipun cocok dibelajarkan dengan strategi pembelajaran ekspositori, namun strategi Mind Map juga memberikan hasil yang baik ketika dibelajarkan kepada mereka dengan arahan yang maksimal dari guru.

Hasil analisa data penelitian melalui uji Scheffe' diputuskan untuk menerima Ha dan menolak Ho. Hal ini menunjukkan bahwa hasil belajar gambar teknik mesin siswa yang diajar dengan menggunakan strategi Mind Map dengan gaya belajar kinestetik lebih tinggi tinggi daripada siswa yang diajar menggunakan strategi pembelajaran ekspositori yang memiliki gaya belajar kinestetik.

Mind merupakan gagasan berbagai imajinasi. Mind merupakan suatu keadaan yang timbul bila otak (brain) hidup da sedang bekerja (Taufik Bahaudin, 1999: 53). Lebih lanjut Bobbi de Porter dan Hernacki (2007: 152) menjelaskan, peta pikiran merupakan teknik pemanfaatan keseluruhan otak dengan menggunakan citra visual dan prasarana grafis lainnya untuk membentuk suatu kesan yang lebih dalam. Peta pikiran adalah teknik meringkas bahan yang akan dipelajari dan memproyeksikan masalah yang dihadapi ke dalam bentuk peta atau teknik grafik sehingga lebih mudah memahaminya Iwan Sugiarto, 2004: 75).

Pada siswa dengan gaya belajar kinestetik dengan karakteristik yang antara lain, pertama adalah menerima informasi/pelajaran dengan cara menyentuh, berdiri berdekatan dan banyak bergerak, kedua, saat membaca sambil menunjuk tulisan. Ketiga anak tidak bisa/tahan duduk terlalu lama untuk mendengarkan pelajaran biasanya menuntut cara belajar dengan pergerakan. Pendekatan belajar yang efektif pada anak dengan tipe kinestetik adalah melalui pengalaman atau dengan menggunakan. Cara lain yang juga bisa digunakan adalah secara tetap membuat jeda di tengah waktu belajar. Tak jarang, orang yang cenderung memiliki karakter Kinestetik juga akan lebih mudah menyerap dan memahami informasi dengan cara menjiplak gambar atau kata untuk belajar mengucapkannya atau memahami fakta. Dengan strategi Mind Map, siswa dengan gaya belajar kinestetik dapat dengan mudah membangun pemahaman dengan mengembangkan kretifitas sendiri secara mandiri. Berbeda dengan strategi belajar ekspositori yang didominasi oleh guru, yang cenderung membosankan bagi tipe belajar kinestetik. Bermain sambil belajar adalah cara efektif untuk siswa dengan tipe kinestetik sehingga Hasil belajar gambar teknik mesin siswa yang diajar dengan menggunakan strategi Mind Map yang memiliki gaya belajar kinestetik lebih tinggi daripada siswa yang diajar menggunakan strategi pembelajaran ekspositori yang memiliki gaya belajar kinestetik.

Pemetaan pikiran merupakan teknik visualisasi verbal ke dalam gambar. Peta pikiran sangat bermanfaat untuk memahami materi, terutama materi yang diberikan secara verbal. Peta pikiran bertujuan membuat materi pelajaran terpola secara visual dan grafis yang akhirnya dapat membantu merekam, memnperkuat, dan mengingat kemabali informasi yang telah dipelajari (Eric Jensen, 2002: 95).

Strategi pembelajaran Mind Map merupakan suatu strategi pembelajaran yang menuntut adanya interaksi dua arah antara guru dan siswa, guru hanya berperan sebagai fasilitator, sedangkan siswa akan berperan secara individu mengelola informasi yang telah diperolehnya. informasi yang diperoleh siswa adalah berasal dari berbagai sumber sesuai dengan tingkat kemampuan siswa dalam membangun informasi yang diperolehnya tersebut. Dengan pengetahuan guru dalam mengenali karakteristik siswa yaitu gaya belajarnya maka semakin mempermudah proses pembelajaran di mana pada akhirnya membantu memaksimalkan proses pembelajaran. Berdasarkan hal tersebut, siswa yang memiliki gaya belajar kinestetik akan lebih mudah untuk bereksplorasi dan menggali lebih dalam lagi konsep yang diperoleh dengan melakukan berbagai aktivitas lewat eksprimen untuk dapat memecahkan masalah yang diberikan pada saat proses pembelajaran yang 
Strategi ekspositori adalah strategi yang tidak banyak menuntuk keaktifan atau keterlibatan siswa. Dalam strategi ini, guru akan memiliki peran utama dalam menjelaskan dan memaparkan materi pelajaran, sementara siswa memperhatikan dan mengelola informasi dari guru berupa ingatan dan hafalan. Pada strategi ini, siswa dengan gaya belajar visual akan dapat melakukan proses belajarnya dengan baik, tanpa terganggu dengan strategi yang diberikan. Pada strategi ini, siswa dengan tipe belajar visual tetap dapat menangkap pelajaran yang diberikan lewat belajar yang bertumpu pada indra visual mereka dan melakukan proses mengingat dan menghafal materi yang mereka lihat .

Sedangkan untuk strategi Mind Map yang menuntut keterlibatan siswa secara mandiri dalam proses belajar, akan menimbulkan kesulitan tersendiri bagi siswa dengan gaya belajar visual. Hal ini disebabkan karena mereka terbiasa pasif dan menerima begitu saja apa yang diberikan oleh gurunya. Mereka akan kesulitan menghubungkan materi pelajaran yang diterima dengan cara membuat rangkuman peta pikiran sacara pribadi dengan mengembangkan kreatifitas mereka. Sehingga Hasil belajar gambar teknik mesin siswa yang diajar dengan menggunakan strategi ekspositori yang memiliki gaya belajar visual lebih tinggi daripada siswa yang diajar menggunakan strategi pembelajaran Mind Map yang memiliki gaya belajar visual.

\section{PENUTUP}

Berdasarkan hasil penelitian dan pembahasan yang dikemukakan sebelumnya, maka dapat simpulkan bahwa :

1. Hasil belajar gambar teknik mesin siswa yang diajarkan dengan Strategi Mind Map lebih tinggi dibandingkan dengan hasil belajar gambar teknik mesin siswa yang diajarkan dengan Strategi pembelajaran ekspositori.

2. Hasil belajar gambar teknik mesin siswa yang memiliki gaya belajar kinestetik lebih tinggi daripada siswa yang memiliki gaya belajar visual.

3. Terdapat interaksi antara Strategi pembelajaran dan gaya belajar yang memberikan perbedaan pengaruh terhadap hasil belajar gambar teknik mesin siswa. Perbedaan pengaruh tersebut adalah: (1) Hasil belajar gambar teknik mesin siswa dengan gaya belajar kinestetik yang diajar dengan Strategi Mind Map lebih tinggi daripada hasil belajar siswa dengan Strategi pembelajaran ekspositori; (2) Hasil belajar gambar teknik mesin siswa dengan gaya belajar kinestetik yang diajar dengan Strategi Mind Map lebih tinggi daripada hasil belajar siswa dengan gaya belajar visual yang diajar dengan Strategi pembelajaran ekspositori; (3) Hasil belajar gambar teknik mesin siswa dengan gaya belajar kinestetik yang diajar dengan Strategi pembelajaran ekspositori lebih rendah daripada hasil belajar siswa dengan gaya belajar visual yang diajar dengan Strategi pembelajaran ekspositori; (4) Hasil belajar gambar teknik mesin siswa dengan gaya belajar kinestetik yang diajar dengan Strategi Mind Map lebih rendah daripada hasil belajar siswa dengan gaya belajar visual yang diajar dengan Strategi pembelajaran ekspositori; (5) Hasil belajar gambar teknik mesin siswa yang diajar dengan Strategi Mind Map lebih tinggi daripada hasil belajar siswa yang diajar dengan Strategi pembelajaran ekspositori; dan (6) Hasil belajar gambar teknik mesin siswa dengan gaya belajar kinestetik lebih tinggi daripada hasil belajar siswa dengan kemampuan gaya belajar visual.

\section{DAFTAR PUSTAKA}

Anderson, O.W. dan Krathwohl, D.R. 2001. Taxonomy for Learning, Teaching, and Assessing. New York: Addison Wesley Longman, Inc.

Arends, R. 2008. Learning To Teach. Yogjakarta: Pustaka Pelajar.

Ary, D. Jacobs, L.C Razavieh, A. (1982). Pengantar Penelitian Dalam Pendidikan. (Penerjemah Furcham, A). Surabaya : Usaha Nasional.

Bobbi DePorter, Dkk .2007. Quantum Teaching. Bandung : Penerbit Kaifa.

Djamarah, Saiful.2006.Strategi Belajar Mengajar.Jakarta : Rineka Cipta.

Dahar, Ratna Wilis. 1989. Teori-Teori Belajar. Bandung : PT. Gelora Aksara Pratama.

Dick, W. \& Carey, L. 2005. The Systematic Design of Instruction. Glenview, Illinois: Scoot, Foresman and Company.

Frick, Heinz. 2003. Ilmu Konstruksi Stuktur Bangunan. Yogyakarta : Kanisius

Gagne, R. M. 1977. The Condition of Learning. New York: Halt Rinerhart and Winston. 
Gerlach and Elly. 1980. Teaching and Media Asystematic Approach. Englewood Cliffs, N.J.

Gunawan A.W. 2007. Born to be A Genius. Jakarta: Gramedia Pustaka.

Hernowo. 2004. Vitamin $T$ : Bagaimana Mengubah Diri Lewat Membaca dan Menulis. Bandung : Mizan Learning Center.

2005. Quantum Reading : Cara Cepat nan Bermanfaat Untuk Merangsang Munculnya Potensi Membaca. Bandung : Mizan Learning Center.

Juhana 0, Suratman M. 2000. “Menggambar Teknik Mesin”. Bandung : Pustaka Grafika.

Lassei. 1986. The Great of Brain. New York: Macmillan Company.

Lazzader. 2003. Menggambar Teknik Dasar. Jakarta: PT. Gramedia

Munandar, Utami. 1998. Memupuk Bakat dan Kreativitas Siswa Sekolah Menengah. Jakarta: PT. Gramedia

Nasoetion, N. dan Suryanto. A. Tes, Pengukuran, dan Penilaian. Jakarta: Pusat Penerbitan UT. 2002.

Nasution, S. 2005. Berbagai Pendekatan Dalam Proses Belajar dan Mengajar. Jakarta : Bumi Aksara.

Nurhadi. 2003. Contextual Teaching and Learning. Jakarta: Depdikbud Dirjen Dikti.

Prawiradilaga, D.S. 2007. Prinsip Desain Pembelajaran. Jakarta : Kencana

Rakhmat, Jalaluddin. 2006. Belajar Cerdas. Bandung : Mizan Learning Center.

Runi. 2005. Pengaruh Strategi pembelajaran Terhadap Kemampuan Pemecahan Masalah Matematika Siswa. Jurnal Karya ilmiah.(online)(http://Gurukreatif.wo ordpress/2004/02/05/ptk/qt)

Sanjaya, Wina. 2009. Strategi Pembelajaran Berorientasi Standar Proses Pendidikan. Jakarta : Kencana Prenada Media Group

Sato G.T., Hartanto N.S. 2005. “Menggambar Teknik Mesin Menurut Standar ISO”. Pradnya Paramita.

Shindunata. 2000. Mengagas Paradigma Baru Pendidikan. Jakarta : Kanisius.

Soemanty, Wasty, 1984, Psikologi Pendidikan. Jakarta : Bina Aksara

Seels, B.B \& Richey. 1994. Instructional Technology : The Defenition and Domain of Field. Washington, DC : AECT.
Suryosubroto, B. 2009. Proses Belajar Mengajar Disekolah. Jakarta : Rineka Cipta.

Snelbecker, G. 1974. Learning Theory, Instructiona Theory, and Psychoeducational Design. New York: McGraw-Hill Book Company.

Tan, O.S. 2004. Students' experiences in problem-based learning: Three Blind Innovations in Education and Teaching International. Singapore: Thomson Learning.

Uno, H. 2008. Perencanaan Pembelajaran. Jakarta: Bumi Aksara.

Winkel, W. S. 2007. Psikologi Pengajaran. Yogyakarta: Media Abadi.

Wena,M. 2009. Strategi Pembelajaran Inovatif Kontemporer. Jakarta: Bumi Aksara.

Windura, Sutanto. 2008. Mind Map Langkah Demi Langkah. Jakarta : Elex Media Komputindo 